\title{
الإصلاح الإداري
}

هفهوهـه.. وآليات تطبيقه..(دراسة هقارنة)

\author{
د. اسحر عبدالاله الصمدي \\ دكتور اه في الاقتصاد
}
وزارة المالية - قطاع الشئون الاقتصادية
مجمع الوزارات بلوك V الدور الأول
+965-97101001\9900785

.999099... $140 \%$. 990971.1..1

sahar@transparency.org.kw

العنوان المختصر للبحث" الإصلاح الإداري وآليات تطبيقه...

(در اسة مقارنة) (د) 
المجلة العلمية لقطاع كليانه |لنجارة- جامعة الأزهر العدم|لعاشر - يناير سا.؟ 


\section{المجلة|لعلمية لقطاع كليانه النجارة- جامعة الأزهر العدم |لعاشر - يناير سا.؟}

\section{ملخص الدراسة: - ماسة}

يرتبط نجاح تتفيذ أية خطة تتموية بالتقدم الذي تحرزه الدولة في إصــلاح

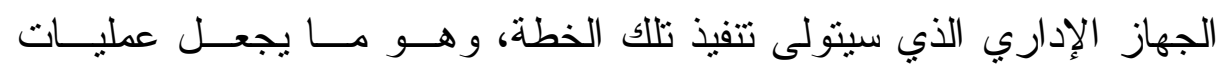

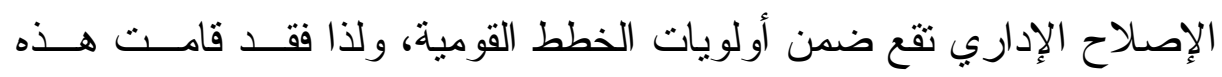

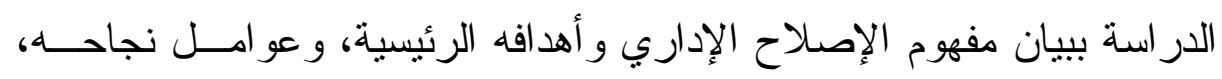

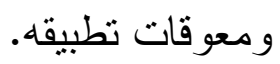

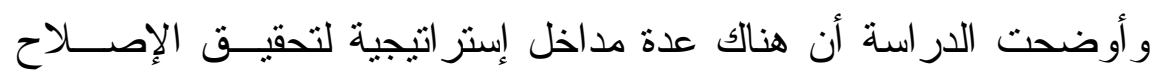

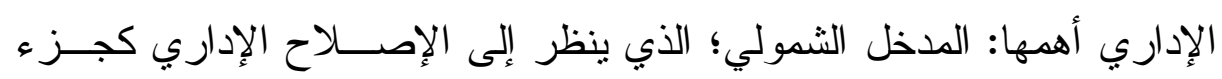

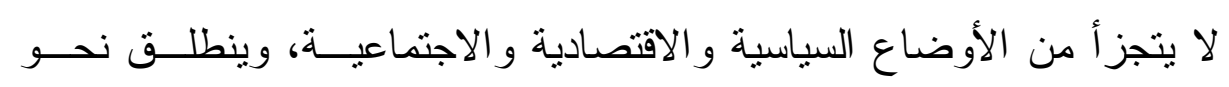
إصلاح الجهاز الإداري في إطار إستراتيجية شاملة للإصلاح.

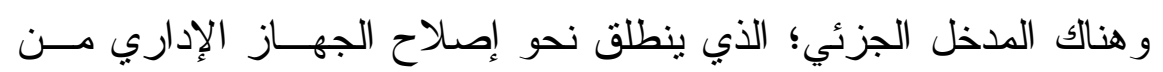

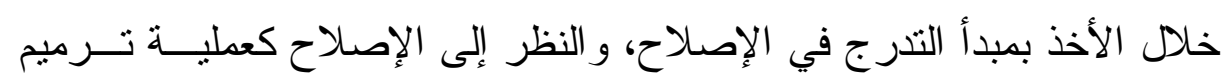
للأجز اء المكونة للجهاز الإداري.

وقد توصلت الدراسة إلى أن عملية الإصلاح الإداري في الدول العربية لم الإدئ

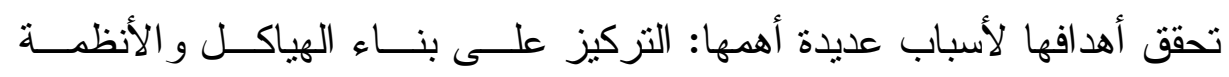

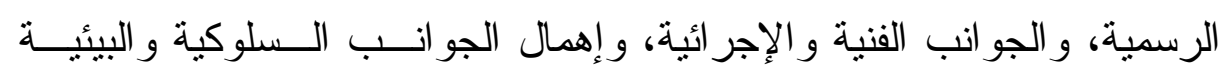

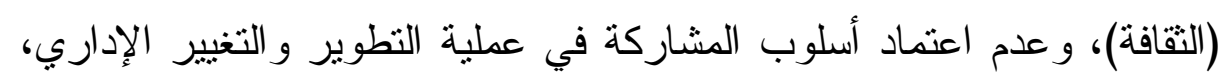
وقصور الإستر اتيجية المجتمعية للتنمية السياسية.

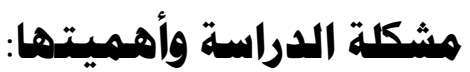

يحتل الإصـلاح الإداري موقعا متميز ا في قائمة الخطط التتموية و القوميــة

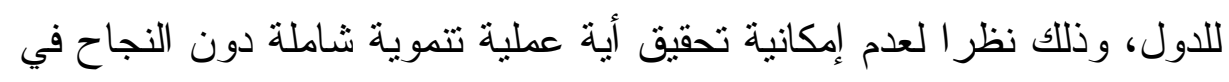
تحقيق الإصلاح الإداري، حيث إن تتفيذ هذه الخطط ينم عبر الأجهزة الإدارية 


\section{المجلة|لعلمية لقطاع كليانه النجارة- جامعة الأزهر العدم |لعاشر - يناير سا.؟}

المختلفة، وكلما ارتقى عمل تلك الأجهزة إلى مستويات عليا من الأداء المــتقن و المحترف حققت الخطط التتموية و القومية أهدافها و العكس صحيح، ولذا فـإن عمليات الإصلاح الإداري لاز الت مشكلة تــؤرق الــدول وخاصـــة الناميــة بالدرجة الأولى، التي لا نزال تزخر في بحر الفساد الإداري، رغم الدحاو لات التي تبذل للخروج منه.

ولذا فإن هذه الدراسة تقوم بإلقاء الضوء على هذا الموضوع وبيان أهميته و أهدافه، وعرض أهم الإستر اتيجيات و الآليات التي تتبعها الدول لتتفيذ عمليات الإصلاح الإداري، مع عرض نماذج من الدول العربية التي تم اختيارها لهــذا

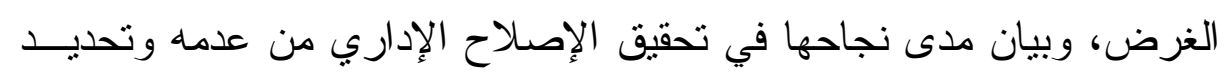

\section{أسبابه.}

\section{هدف الدراسة وأهميتهها:}

تهدف هذه الدر اسة إلى بيان مفهوم الإصــلاح الإداري، وعــرض أهـــ أهداف الإصلاح الإداري، وبيان أهم العوامل المؤثزة على عمليات الإصــلاح الإداري، وتحديد أهم المعوقات و التحديات التي نتواجـهـه عمليـات الإصـــلاح الإداري، كما ستقوم الدراسة ببيان مر احل عمليات الإصلاح الإداري، وأهـــ الإدي، الآليات و الإستر اتيجيات المتبعة في تحقيقه.

\section{هنهمية الدراسة:}

ستقوم هذه الدر اسة باستخدام المنهج الاستقر ائي من خلال تتبع مـــا كتبــــ

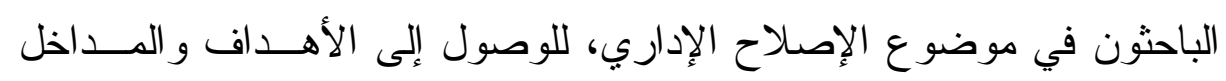

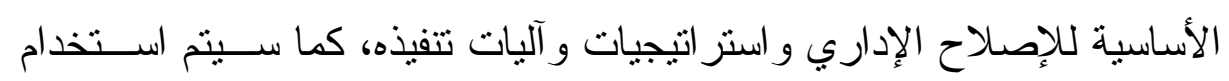

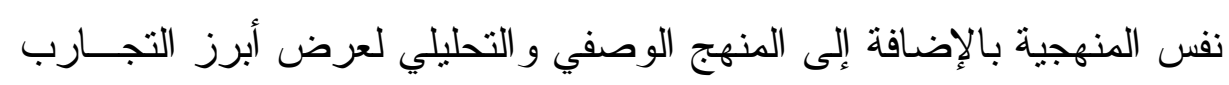




\section{المجلة|لعلمية لقطاع كليانه النجارة- جامعة الأزهر العدم |لعاشر - يناير سا.؟}

العربية المختارة في مجال الإصلاح الإداري. إذ أن الدراسة مقارنة تقوم على

الوصف و التحليل و التقييم (وصفيه تحليليه تقسيميه).

إطار الدراسة (المتتويات):

مشكلة الدر اسة و أهميتها

هدف الدر استة

منهجية الدر اسة

المبحث الأول

مفهوم الإصلاح الإداري

• أهداف الإصلاح الإداري الإدي

• عو امل نجاح الإصلاح الإداري

• معوقات الإصلاح الإداري ل

المبحث الثاني

مداخل الإصلاح الإداري

مر احل الإصلاح الإداري

استر اتيجيات و آليات الإصلاح الإداري

المبحث الثالث

أبرز التجارب العربية في الإصلاح الإداري:

ه التجربة الكويتية.

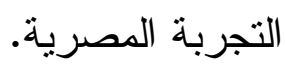

خلاصة البحث و أهم النتائج

قائمة المر اجع و المصادر 


\section{المجلة|لعلمية لقطاع كليانه النجارة- جامعة الأزهر العدم |لعاشر - يناير سا.؟}

\section{المبحث الأول}

\section{ا - تمريف الإصلاح الإداري:}

تم تعريف الإصلاح الإداري بتعريفات عديدة نذكر منها ما يلي:

عرف مؤتمر الإصلاح الإداري في الدول النامية، الذي عقدته هيئة الأمم المتحدة بجامعة ساسكي البريطانية لعام ا9V) (ا، عملية الإصلاح الإداري على

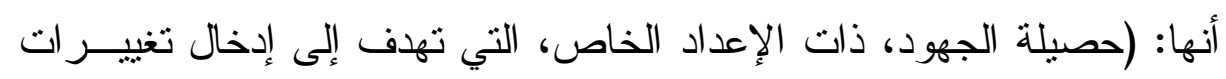

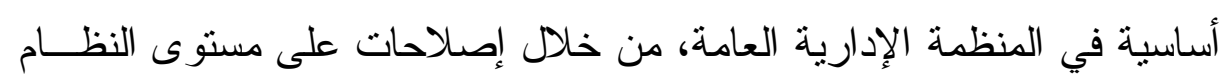
ككل) (')

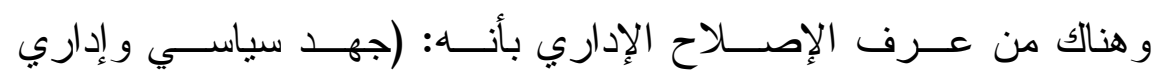
و اقتصادي وتقافي هادف لإحداث تغيير ات أساسية إيجابية في السلوك و الــنظم

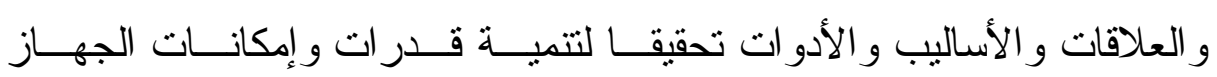
الإداري، بما يؤمن له درجة عالية من الكفاءة و الفعالية في إنجاز أهدافه) (؟).

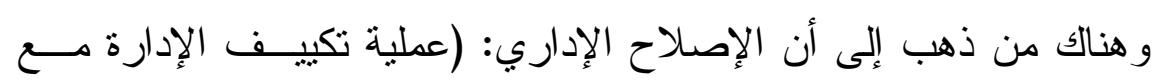

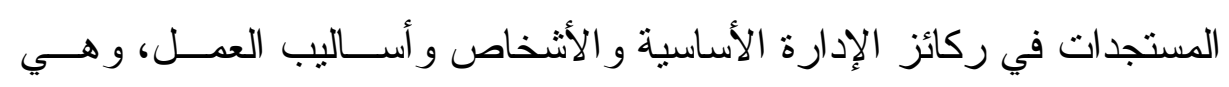
عملية أساسية تعتمد على أثخاص مهيئين) (r).

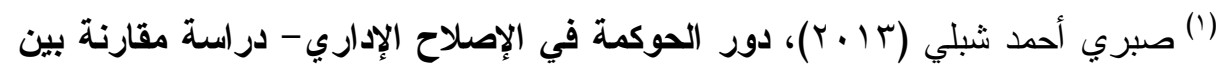

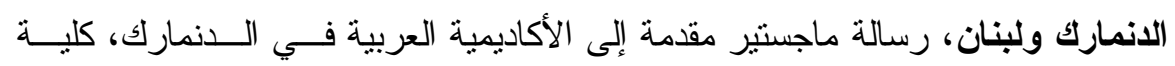

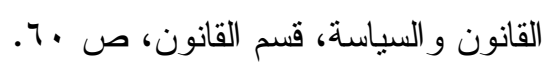

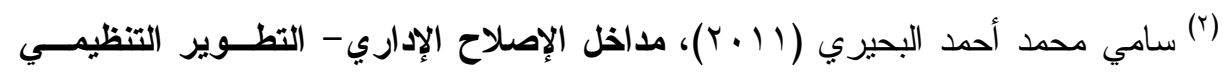

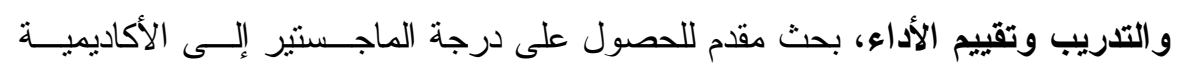

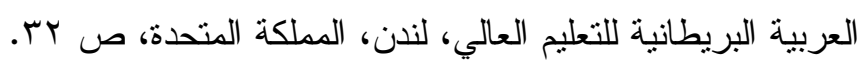

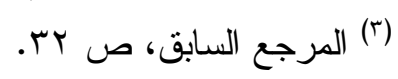




\section{المجلة|لعلمية لقطاع كليانه النجارة- جامعة الأزهر العدم |لعاشر - يناير سا.؟}

وهنالك من عرف الإصلاح الإداري بأنه: (إدخال تعديلات في تتظيــات إدارية قائعة، أو استحداث تتظيمات إدارية جديدة، و إصدار الأنظمة و القـــو انين

و اللو ائح اللازمة لذلك) (').

ويتضح من التعريفات السابقة أن جميع التعريفات التي عرفت الإصــلاح الإداري تتفق على أن الإصلاح الإداري عبارة عـن جهـــ جمــاعي مــنظم يستهدف إحداث تغيير ات هيكلية في الجهــاز الإداري القــائم، بهــدف زيــادة فعاليته، بما يتتاسب مع الظروف السياسية والاجتماعية و الافتصادية الـسائدة، من خلال تحسين أساليب العمل، وتأهيل وتدريب الأفر اد الذين يقودون العملية الإدارية، وتهيئة البيئة القانونية و التشريعية المناسبة، التي ترفع من إمكانيــات الجهاز الإداري، وتحسن من مستوى أدائه.

\section{أهداف الإصلاح الإداري:}

يهدف الإصلاح الإداري إلى تحقيق غايات سياسية واجتماعية و اقتصادية

تناخص فيما يلي (r) (r) 1- تحسين مستوى أداء الجهاز الإداري ورفع إنتاجيته.

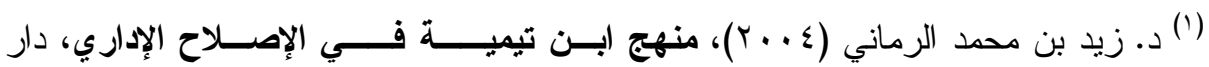

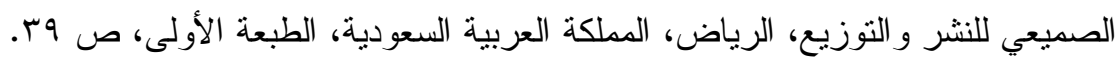

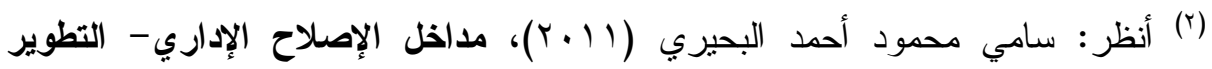

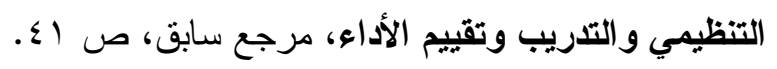

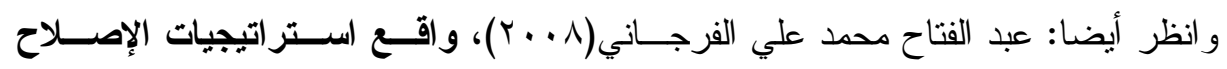

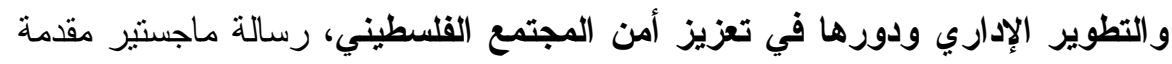

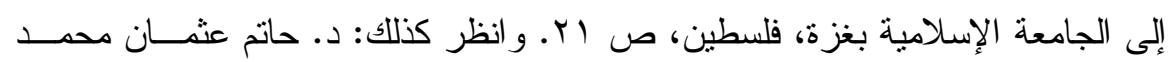

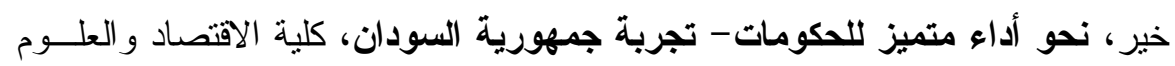

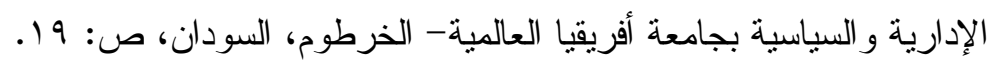




\section{المجلة|لعلمية لقطاع كليانه النجارة- جامعة الأزهر العدم |لعاشر - يناير سا.؟}

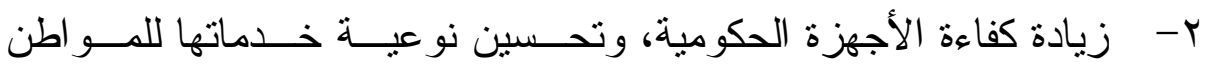

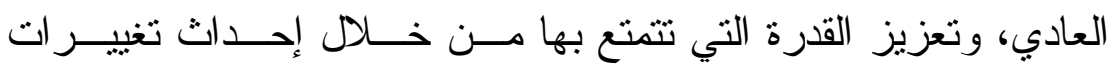
مقصودة في الهياكل التتظيمية، و أساليب الإدارة، وســلوكيات العـاملين فيها.

ب- - ترشيد الإنفاق الحكومي و التزكيز على اقتصاديات التشغيل، من خــلال تخفيض حجم البر امج و الأجهزة و الأعداد الزائدة من العاملين. ع - تعزيز عملية التحول الديمقر اطي، ودعم التوجهات نحــو اللادركزيـــة الإدارية، بهدف تشجيع المشاركة الثعبية في إدارة الثشئون العامة وفـي صنع القرار ات.

0- تبسيط الإجراءات الإدارية، و إصلاح الأنظمة المالية و الضريبة بقـصد توفير الموارد، و العدالة في توزيع الأعباء.

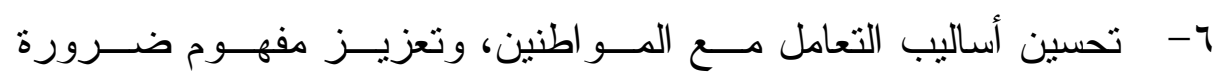
الاستجابة لمطالبهم، باعتبار أن تقديم الخدمة للمو اطنين هو مبرر وجود الأجهزة الإدارية، ويتم ذلك من خلا إظهار مزيد من الثفافية في عمل الموظفين و الأجهزة الإدارية، وتعزيز مفهـوم المـساعلة و المسسئولية الاجتماعية.

-V - وضع السياسات العامة وتتفيذها، بشكل يضمن الكفاءة و الفعالية و العدالة، و الخضو ع للمساعلة عن الأداء.

1- مو اعمة الإدارة العامة مع مهام الدولة، و إثباع حاجات المو اطنين. 9- تحديث وتجديد الإدارة العامة على جميع مستوياتها وفي جميع أبعادهـــا البنيوية و الوظيفية، بما يسهم في القضاء على المشكلات التي تو اجهها. 


\section{المجلة|لعلمية لقطاع كليانه النجارة- جامعة الأزهر العدم |لعاشر - يناير سا.؟}

• 1- التخلب على المشكلات السياسية و الاقتصادية و التتموية و التتظيمية التـي تعاني منها الإدارة العامة، و اقتز اح الحلول المالئمة لها. 11 - مو اكبة الإدارة العامة لمستجدات التحديث من أجل تحقيق غايات الكفاية الإدارية، ومعالجة الانحر اف، ومحاربة الفساد، و القضاء على التعقيدات

$$
\text { و العيوب المرضية. }
$$

Y ا - بناء هيكل الدولة على أسس علمية ووطنية بما يجعلها أكثر قدرة علـى النهوض بأعباء التغير الحضاري المنشود. سا - قيام البناء الإداري على مفهوم الفاعلية و الكفاءة و المبادرة و المو اكبة بما يستشرف أهداف الشعب العليا من خلال:

$$
\begin{aligned}
& \text { البناء التربوي (سلوكاً ومنهجاً). } \\
& \text { التنظيم العلمي و التكنولوجي المعاصر . } \\
& \text { الاهتمام بالعنصر البشري (القيادة و القاعدة). } \\
& \text { تحسين بيئة العمل (الطبيعية و المعنوية). } \\
& \text { تطوير ومو اكبة أطر النتريع الإداري. }
\end{aligned}
$$

\section{عواهل نجاح الإصلاح الإداري:}

يتوقف نجاح جهود الإصلاح الإداري على توفر العديـــــــن العوامـلـل

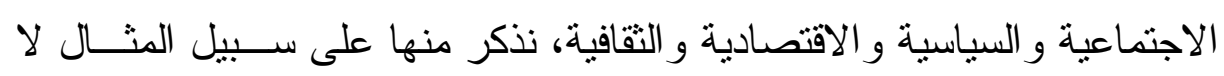

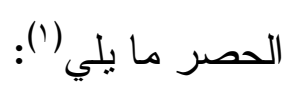

(') أ.م.د. عادل طالب سالم، ومها فاروق عزت، أهمية العوامل المــؤثرة فــي الإصــلاح

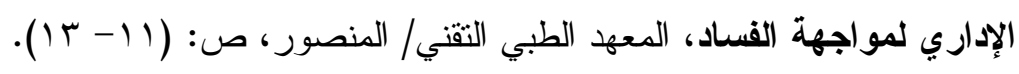




\section{المجلة |لعلمية لقطاع كليانه النجارة- جامعة الأزهر العدم |لعاشر - يناير سا.؟}

1- بناء دولة القانون و المؤسسات، التي يسودها تطبيق القانون بمنأى عـنـ الاستخلال و الرشوة و المظاهر الفاسدة، و أن بحظى هذا التوجــه بــدعم مباشر من أعلى قمة في السلطة التنفيذية، مع تعزيز استقلالية القـضاء، وترسيخ الديمقر اطية، وحماية حقوق الإنسان.

r- الاهتمام بالعنصر البشري، من خلال بناء نظام كــف للتعيـين علــى

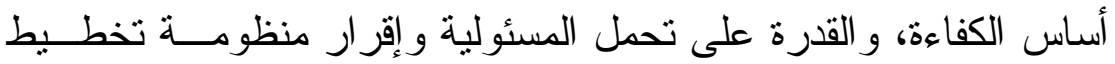
المسار الوظيفي على أساس الكفاءة وحدها دون غيرها. r- تفعيل الإجراءات الإدارية المتبعة في الإعداد لتولي الوظيفة العامة، بما يخلق فرصا منساوية لجميع المو اطنين من حيث شروط التقديم للوظائف العامة، و اختبار الكفاءة، وإجر اء امتحانات اللغة و الثقافة، خاصــة فـي الدو ائر الحساسة، أو التي تمثل أجهزة الدولة، بالإضافة إلى الاســتعلام الكافي عن السيرة الذاتية و الحياتية للمتقدم للوظيفة، و التحقق من نز اهته وسمعته قبل تولي الوظيفة المطلوبة. ع - تحقيق التو ازن بين الحقوق و الو اجبات تجاه الأشخاص المعينـين وبــين بعضهم البعض، مع تطبيق مبدأ التوازن بــين الثــواب و العقــاب فـي محاربة الفساد، ومحاسبة المقصرين في أداء و اجباتهم. 0- - تكليف الأشخاص ذوي الكفاءة و النز اهة المطلوبة من الناحيـــة العلميـــة و العملية، و الذين يملكون المهار ات المطلوبـــة لأداء الأعمـــال الموكلـــة إليههم، و القدرة على المتابعة الفعالة عند النتفيذ للمستويات المتعددة فـي الهرم التتظيمي، مع مر اعاة عدم اقتصـار الكفاءة على توفر المــؤهلات العلمية ذات الطابع الأكاديمي فقط، بل يجب أن يتمتع الثخص المرشح للوظيفة العامة الاستعداد الذاتي على استخدام مؤهلاته المكتـسبة فـي 


\section{المجلة|لعلمية لقطاع كليانه النجارة- جامعة الأزهر العدم |لعاشر - يناير سا.؟}

استثمار جميع الطاقات البشرية المتوفرة لديه، وجعلهـــا تعدـل كفريـق واحد في إنجاز الأعمال الموكلة إليه، وكذلك قدرته على التعامل بكفاءة

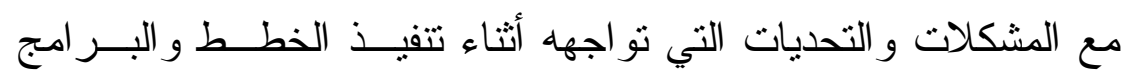
الموضو عة.

7- إعادة تقييم الدورات المستتدية و الأنظمة المالية المطبقة، و إعادة هيكلتها بما يحقق رفع كفاءة الأداء، وسلاسة سير الأعمال، وســرعة الإنجــاز ، وهو ما بتطلب تقوية إجر اءات و أنظمة الضبط و الرقابة الداخلية، للحـــ من الخروقات التي تؤدي إلى الفساد المالي و الإداري.

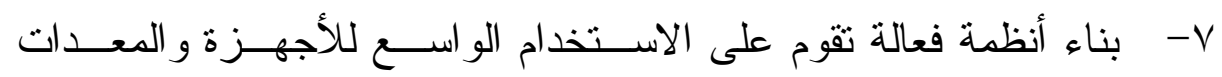
المنطورة في العمل، وصو لا إلى تطبيقات الحكومة الإلكترونية، لتحقيق السر عة و الدقة في إنجاز الأعمال وخدمة المو اطنين.

-1 - وضع بر امج تدريبية مدروسة لرفع كفاءة العاملين من الناحية المهنيــة و السلوكية في ضوء دراسة الاحتياجات التدريبية الفعلية و إعداد البر امج المناسبة لها.

9- إنثاء هيئات ومر اكز قياس وتقييم الأداء، التي تعنى بمر اقبة ومر اجعــة وتقييم أداء الأجهزة الحكومية، وتقييم نوعية الخدمات و الــسلع المقدمــة للمو اطنين، و التأكد من أنها مطابقة للمو اصفات و المقاييس المتقق عليها، وكذلك الإشر اف على إعداد المناقصات العامة وشروط الــدخول فيهــا، لضمان الاستخدام الأمنل للموارد المالية، بما يضمن المحافظـــة علــى درجة عالية من الجودة في السلع و الخدمات المقدمة للجمهور • • 1- العمل على إثر الك أكثر من جهة للقيام بمهمة نوفير السلع الاســتهلاكية

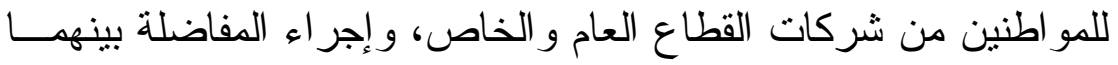




\section{المجلة|لعلمية لقطاع كليانه النجارة- جامعة الأزهر العدم |لعاشر - يناير سا.؟}

على أساس النوعية و السعر، مع تهيئة جو من المنافسة الثريفة، وتكافؤ الفرص، بما يساهم في توفير أفضل الخدمات للمو اطنين، مــع تحقبــق أرباح مناسبة (تطبيق مبدأ استرداد تكلفة الخدمة).

11 - تقعيل دور الغرف التجارية و الصناعية في مر اقبة حسن تتفيذ الأعمـال

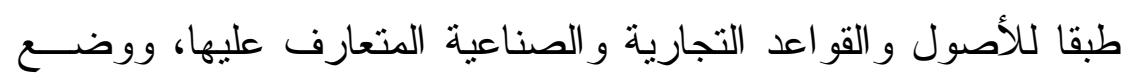
ضو ابط محددة لمحاسبة المقصرين مهنيا. r إ - إعادة هيكلة أجهزة الرقابة و التدقيق، على نحو يخدم الاتـسجام فيهــا، وتوزيع مر احل الرقابة و التدقيق إلى مرحلة ما قبل وبعد الصرف، مـــع مر اعاة تحقيق التكامل في عمل تلك الأجهزة، ومنع الازدو اجية في أداء أعمالها.

\section{هموقات الإصلاح الإداري:}

هناك الكثير عدد من المعوقات والتحديات و التي تو اجه عمليات الإصلاح الإداري، وتعيق تتفيذ البر امج و الخطط الموضو عة على أسس سليمة تـضنمن تحقيق الأهداف التي وضعت من أجلها، أهمها ما يلي ('):

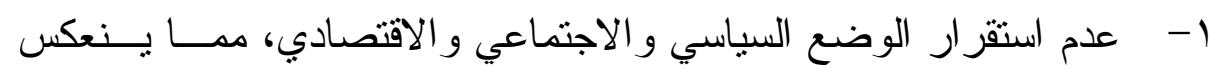
سلبا على الخطة القومية الموضوعة.

r- عدم جدية الأجهزة الحكومية في تطبيق التوجيهــات المركزيـــة بــشأن

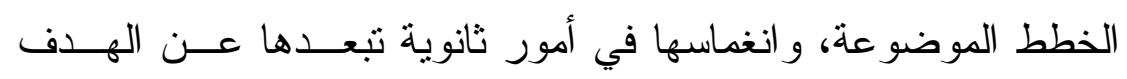
المركزي، رغم توفر الإمكانيات ورغبة الكثيرين في عملية الإصــلاح الإداري في مختلف المستويات الإدارية.

(') أ.م.د. عادل طالب سالم، ومها فاروق عزت، أهمية العوامل المــؤثرة فــي الإصــلاح

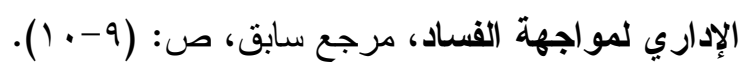




\section{المجلة|لعلمية لقطاع كليانه النجارة- جامعة الأزهر العدم |لعاشر - يناير سا.؟}

r- عدم وضوح الأهداف المطلوبة في عملية الإصلاح الإداري، مما يؤدي

إلى حدوث إربالك يعيق توجيه المسار الصحيح، ويحدث انحر افــا فــي تطبيق الخطط الموضو عة.

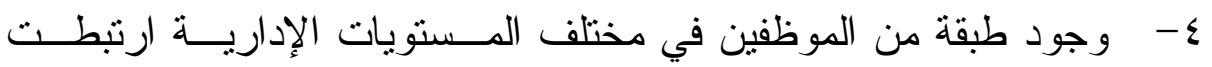
مصالحها بالفساد و الانحر اف الإداري، وقسم منها يحتل مو اقع بـارزة، تطيح بكل البر امج الموضوعة، وتحاول إفثال أية محاولـــة للإصــلاح

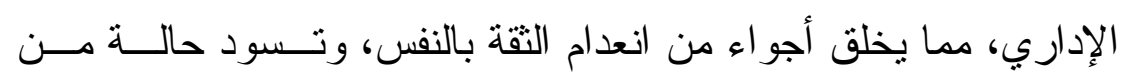

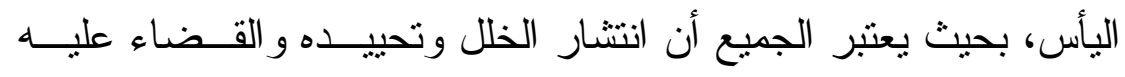
أصبح حلما غير قابل للتحقيق. 0- - انثغال الناس بالطابع الاستهلاكي متأثرين بالدعاية الغربية، و الابتعــاد عن الدافع الوطني، و اهتمامهم بالتسوق، وتقليد الغــرب فــي الأثـــياء و الجو انب السيئة، و عدم مساعدة الحكومات في تطبيق عمليات وبــر امج

$$
\text { الإصلاح الإداري. }
$$

ד- ضعف التوجيه الأسري، وحصر تفكير رب العائلة على توفير متطلبات

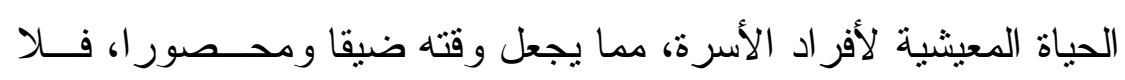
وقت لديه لمتابعة الأبناء وتوجيههم، وتـربيتهم علـى أسـس سـليمة ومتكاملة. - - - كثافة التوجه الإعلامي الغربي، و التي تعمل على إبعاد الناس عن القـيم و المبادئ الأخلاقية، مما يؤدي إلى إهمال الأمــور الحــساسة و المهــــة و المصيرية للمجتمع، و الاكتفاء بأمور هامشية وغير نافعة فــي عمليــة

$$
\text { الإصلاح الاجتماعي. }
$$




\section{المجلة|لعلمية لقطاع كليانه النجارة- جامعة الأزهر العدم |لعاشر - يناير سا.؟}

1- - ضعف البر امج التعليمية و التزبوية التي تؤدي إلى نشوء أجيال متعلمــة سطحيا ينقصها الوعي و القدرة على معرفة الطريـق الــصحيح لبنــاء مستقبلها، بسبب انغماس المجتمع بالإنترنت و الفضائيات، و الابتعاد عـنـ الموروث الحضاري للأمة، الذي يجسد الأخلاقيات و المعــايير النظيفــة و السليمة المستتبطة من الأديان السماوية و القيم الأخلاقية. 9- نشوء طبقة و اسعة من الناس غير المتعلمة وغير الو اعيـة، تحــاول أن تكسب وتنزي بشكل سريع بأساليب ملتوية، نشجع البقية علــى الكـسب غير المشروع، و الانحر اف عن المبادئ الأخلاقية، مما يؤدي إلى وجود طبقتين في المجتمع إحداهما: فقيرة ومحرومة وأخرى غنية. • 1- تعاقب المديرين على الوظيفة الو احدة في فترات قصيرة مما يفقد القرار احد أركانه (القبول و التوقيت). 


\section{المجلة|لعلمية لقطاع كليانه النجارة- جامعة الأزهر العدم |لعاشر - يناير سا.؟}

\section{المبحث الثاني}

\section{هداخل الإصلاح الإداري: - مدار}

هنالك عدة مداخل إدارية ينبناها الباحثون حول عمليات الإصلاح الإداري،

أهمها مدخلان رئيسيان هما:

\section{أولا: المدخل الشسمولي ('):}

يقوم هذا المدخل على أساس استخدام النظام المفتوح (Open System)، و الذي يعنى بدر اسة الظو اهر الإدارية في إطار تفاعلها مع البيئــة المحيطــة، حيث يتم النظر إلى عملية الإصلاح الإداري كجزء لا يتجز أ مــن الأوضــاع الإدئ السياسية و الاقتصادية و الاجتماعية، إذ لا يمكن أن يتصور إمكانية تحقيق نجاح كامل لجهود الإصلاح دون أن تكون جزءا من إستر اتيجية شاملة للإصــلاح،

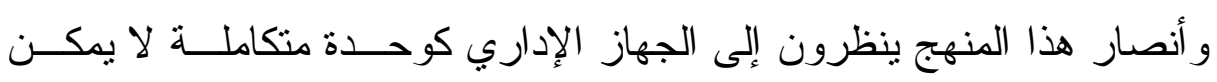
تجزئته، أو معالجة مشاكله بأساليب وحلول جزئية، كما أن هذا المنهج لا يقبل أسلوب التدرج أو عملية التزميم الجزئي للجهاز الإداري.

ويقوم هذا المنهج على عدة محاور منها ما يلي(؟):

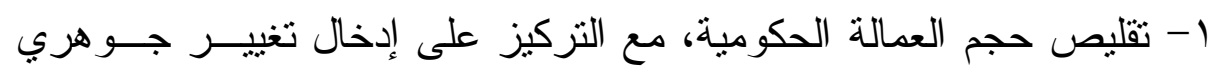
على أسلوب أداء الأجهزة الحكومية وتطوير مهار ات العاملين فيها. ץ- الإدارة الحكومية بأسلوب و عقلية القطاع الخاص؛ وذللك من خلال تبنـي عدة عناصر وقو اعد مستمدة من اقتصاديات السوق داخل الجهاز الإداري (') سامي محمد أحمد البحيري (1) (1)، مداخل الإصلاح الإداري، مرجـع سـابق، ص: .$\leqslant 9-\varepsilon \wedge$

(r) الدكتورة/ عالية عبد الحميد عارف، نظرة نقدية لبرامج الإصلاح الإداري فــي مـصر

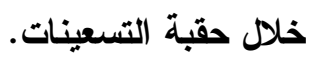




\section{المجلة|لعلمية لقطاع كليانه النجارة- جامعة الأزهر العدم |لعاشر - يناير سا.؟}

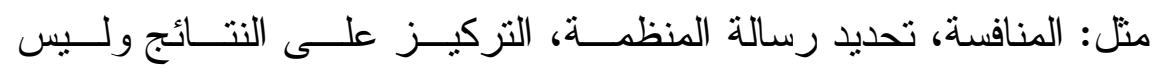
المدخلات.

ب- خصخصة الوحدات الحكومية؛ ويستتد هذا الأسلوب إلــى تفعيـل آليــات

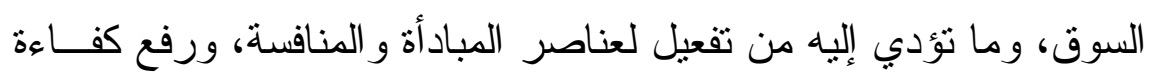
المعاملات، وزيادة فعالية الأداء.

\section{ويتوقف نجاح هذا المنهج على عدة عوامل أهمها منها ما يلي ('):}

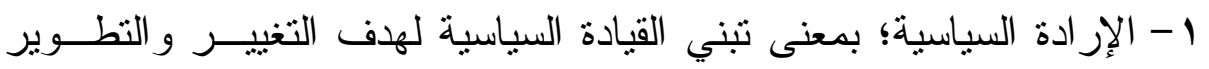
الإداري الثامل. - (الإده

r- المقومات المجتمعية الكلية التي تدعم وتؤازر إصلاح نظم إدارة الجهـاز الحكومي.

r- فعالية الدور الرقابي الخارجي للمؤسسة النتريعية و غيرها من مؤسـسات الرقابة الخارجية على الحكومة.

ع - تطوير وتغيير نظم التعليم و البناء الاجتماعي (هيكل القـيم و الـسلوكيات (السائدة).

ه- تضافر الجهود التطويرية لتتمية الجوانب المجتمعية الأخــرى الـسياسية و الاقتصادية و الاجتماعية.

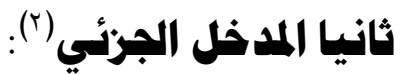

يرى أنصار هذا المنهج ضرورة إتباع أساليب جزئية ومرحلية لمعالجـــة المشكلات التي نو اجه الجهاز الإداري، من خلال التركيز على إصلاح الهياكل

(') عبد الفتاح محمد علي الفرجاني، واقع استراتيجيات الإصــلاح الإداري ودورهــا فـي : عزي

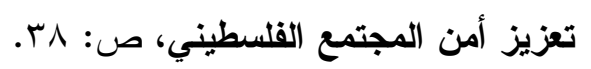

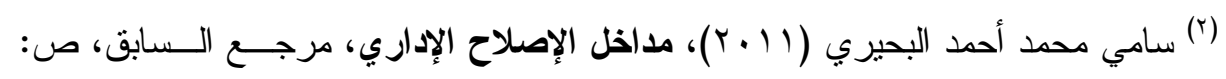
.0. - ะ 9 . 


\section{المجلة|لعلمية لقطاع كليانه النجارة- جامعة الأزهر العدم |لعاشر - يناير سا.؟}

التنظيمية، وتبسيط الإجر اءات، ولذا فإن أنصـار هذا المــنهج ينظــرون إلــى

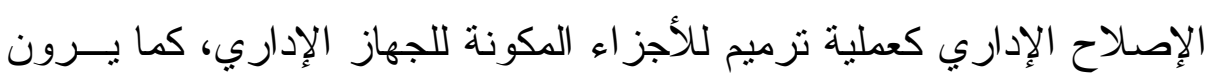
أن الأخذ بمبدأ التدرج سيؤدي إلى إصلاح الجهاز الإداري بشكله الكلي، ولكن يعاب على هذا المدخل أنه قد يخدم مصالح ضيقة في المنظمة، كتعديل الهياكل

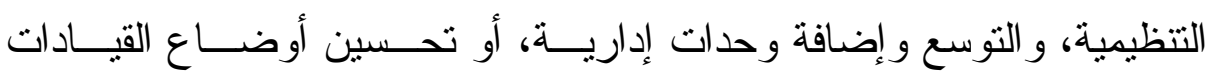

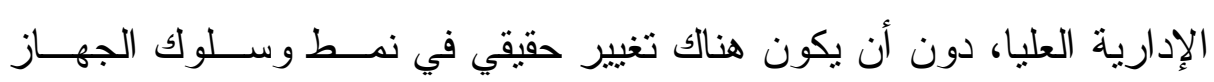

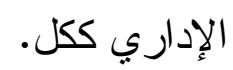

ويقوم هذا المنهج على عدة محاور رئيسية أهمها ما يلي:

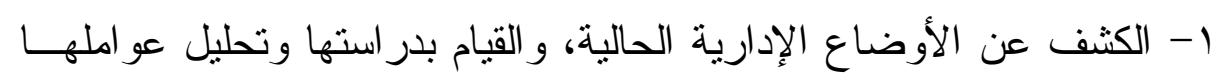
المختلفة.

r- تحديد مصادر المشكلات و أسباب التخلف الإداري. r- التعرف على المتغير ات المؤثرة و المسببة للتخلف الإداري.

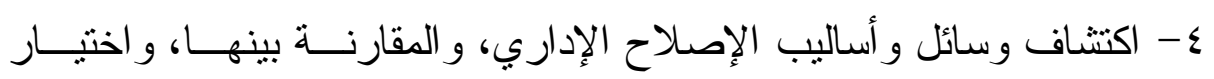
الأنسب للمعطيات و الظروف السائدة. 0- المتابعة وتقييم النتائج. وتوضـح تجارب الإصـلاح في الدول العربية في مجال الإصــلاح الإداري وجود التزكيز على هذا المدخل الجزئي، الذي يقدم إصلاحات جزئية للمشاكل

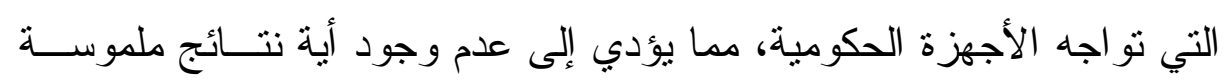
للبر امج الإصلاحية المنفذة.

\section{هراحل الإصلاح الإداري:}

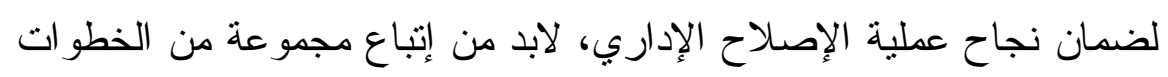

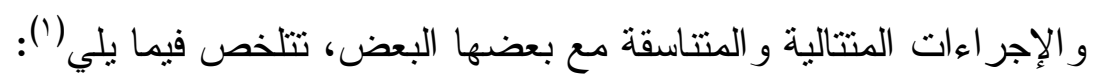

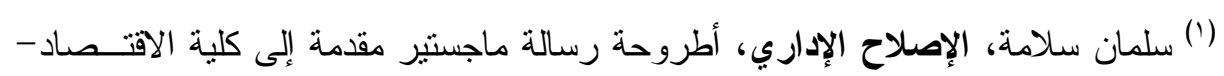
جامعة دمشق، إدارة الأعمال، التاريخ (بدون). 


\section{المجلة|لعلمية لقطاع كليانه النجارة- جامعة الأزهر العدم |لعاشر - يناير سا.؟}

\section{أولا: دراسة وتتليل الهاجة إلى 1الإصلام الإداريى:}

فسوء أداء العديد من الأجهزة الحكومية، وتدني مستوى رضا المستفيدين من خدماتها، وتعقد الإجر اءات الإدارية، و التضخم الوظيفي، وضعف مسستوى

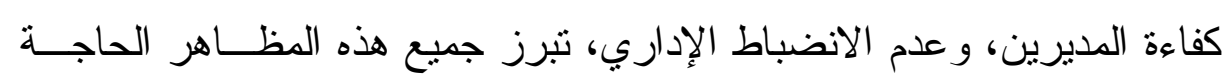

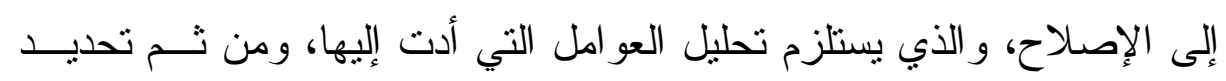
الحلول المتلى لمعالجتها، على ضوء المو ارد المالية و البشرية المتاحة.

\section{ثانيا: إعداد وصياغة الإستراتيجيات ووضع الأهداف:}

ويتم في هذه المرحلة إعداد الخطط الإستر اتيجية لعملية الإصلاح الإداري

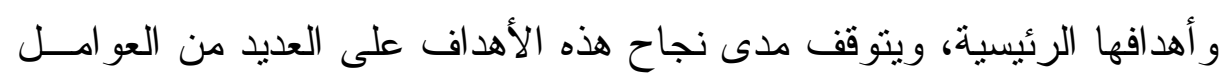

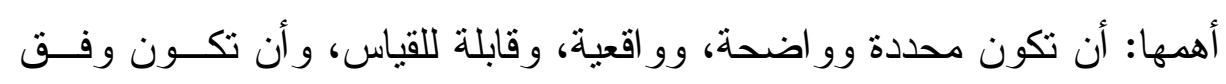
جدول زمني محدد.

وتعتبر هذه المرحلة من أكثر المر احل صعوبة لوجود أولويــات عديـدة

حسب المستقيدين وتفاوت و اختلاف وجهات النظر بـشـأنها وبـشأن وســائل التتفيذ، ومع ذلك فمها اختلفت وتعددت الاستر اتيجيات و المفاهيم فإن الأهداف

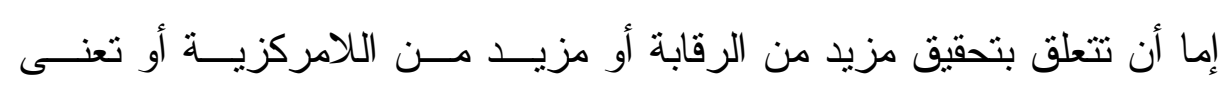
بالعنصر البشري أو بالقو انين أو بالوسائل الثقنية وغيرها.

\section{ثالثا: تطبيق الإصلاح الإداري وتنفيذه:}

وتعتبر هذه المرحلة من أصعب المراحل، نظر الوجود قوى داخل الجهاز

الإداري أو المنظمة تقوم بمقاومة عملية الإصلاح و التغيير، خاصة إذا شعرت

بأن عملية الإصلاح ستؤثز سلبا على مصالحها الثخصية.

وهناك عدة أساليب يتم إتباعها في هذه المرحلة لتتفيذ عمليــة الإصــلاح،

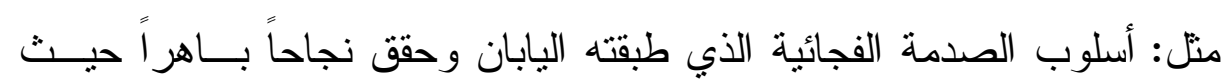




\section{المجلة|لعلمية لقطاع كليانه النجارة- جامعة الأزهر العدم |لعاشر - يناير سا.؟}

وبعد الحرب الثانية قامت بتسريح . . .0 10 موظف دفعة واحدة مـن الجهـاز الإداري للتأكيد على جدية عملية الإصـــلاح ، وهنــاك الأســلوب التــدريجي بالإصلاح أي تهيئة وتأهيل الجهاز الإداري تدريجياً للقيام بعمليــة الإصــلاح

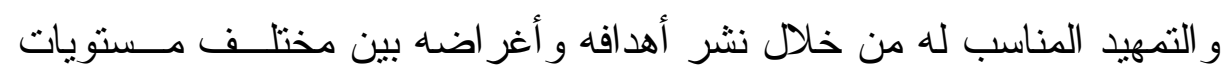
العاملين في الجهاز الإداري قبل البدء به، ومثال على هذا الأسلوب التجربـــة الفرنسية في إصلاح هياكل ونظم الإدارة و الرقابة علة مر افق الكهرباء و الغاز .

\section{رابعا: الرقابة وتقويم الأداء:}

و الرقابة إما أن تكون بعد الانتهاء من عملية الإصلاح، وتــسمى الرقابـــة

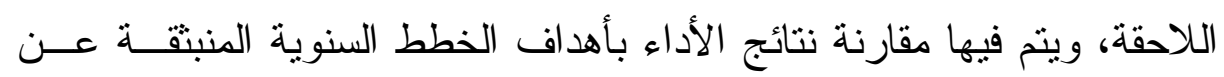
الخطط الإستر اتيجية، وقياس الانحر افات إن وجدت، وتقديم الحلول و البـــدائل المناسبة لمعالجتها. وقد تكون الرقابة مصاحبة لعملية النتفيذ، ويعتبر هذا النوع من الرقابة من

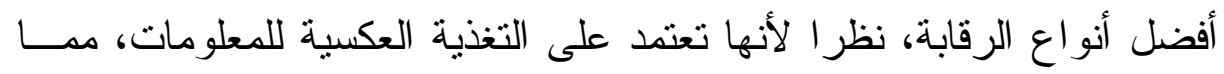
يتيح لمتخذي القرار التخخل في الوقت المناسب، وتقديم التوجيه اللازم لمنفـذي الخطط و البر امج الموضو عة للوصول إلى النتائج المطلوبة.

\section{استراتبيجيات الإصلام الإداريك:}

هناك عدة استر اتيجيات تتبع عالميا لتطبيق عمليــات الإصــلاح الإداري،

$$
\text { أهمها ما يلي (') - (1) }
$$

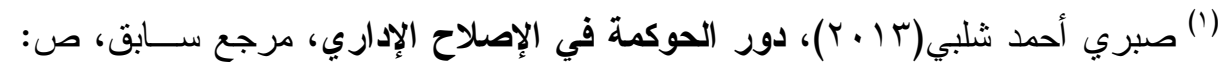

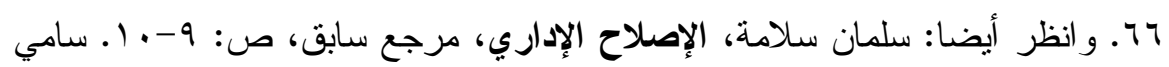

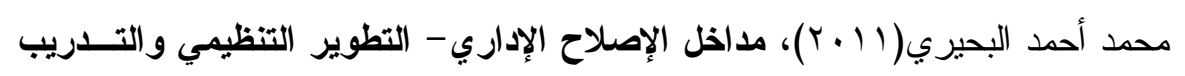

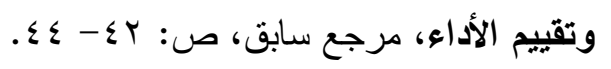




\section{المجلة|لعلمية لقطاع كليانه النجارة- جامعة الأزهر العدم |لعاشر - يناير سا.؟}

\section{أولا: إستتراتيهية الإصلام الجزئي:}

وتقوم هذه الإستر اتيجية على توجيه جهود الإصلاح نحو عدد قليـلـ مسـن

العناصر و المنظمات المستهدفة في عملية الإصلاح، وتقوم هذه الإســتراتيجية

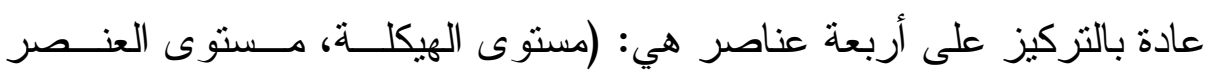
البشري، مستوى طرق و أساليب العمل، الأنظمة و التشريعات).

ثانيا: إستتر اتيهية الإصلام الأفققي:

وتقوم هذه الإستر اتيجية بالتركيز على عدد قليل ومحدود مــن العناصــر

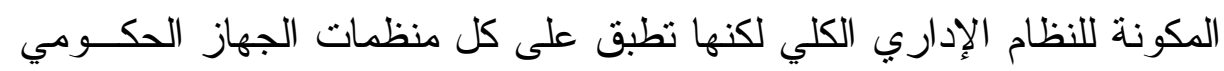

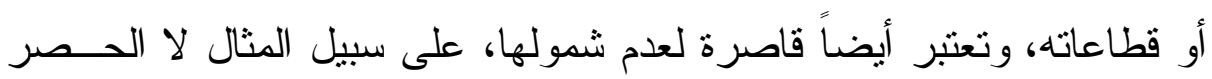

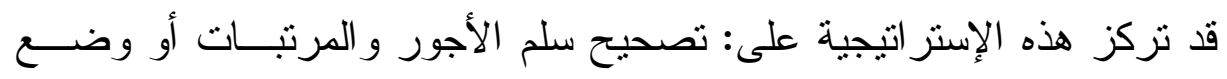

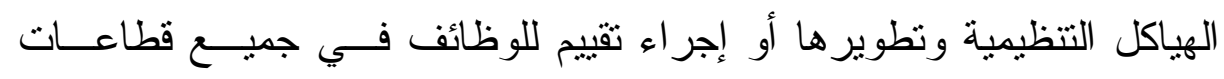
الجهاز الحكومي.

\section{ثالثا: إستنراتيهية 1إصلام القطا عي:}

وتقوم هذه الإستر اتيجية بانتقاء جميع العناصر الحرجة المكونـــة لــلأداء داخل المنظمات الحكومية المختارة، ويتم تجربة بر امج الإصلاح التي ستطبق باءهر على تلك العناصر قبل تعميمها على بقية العناصر ، وذللك من خــلال تـشكيل

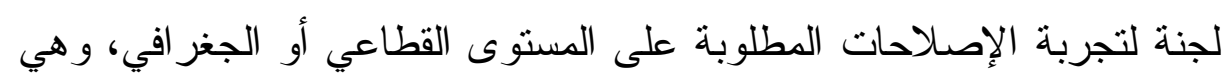
بذللك تعتبر طريقة إدارية مؤقتة للإصلاح تتناسب مع عادات وممارسات عمل الإهل الموظفين، و الوسائل القانونية و الإنسانية التي تقوم بها. وتعتبر هذه الطريقة من وجهة نظر بعض الباحثين ذات آثار إيجابية على عملية الإصلاح الإداري، فهي تدفع الإدارة الثقليدية إلى الثُعور بوجود مهــام

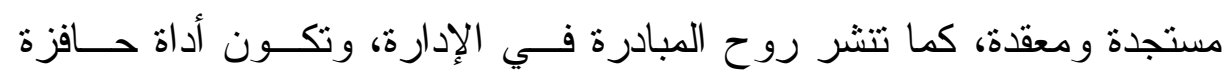

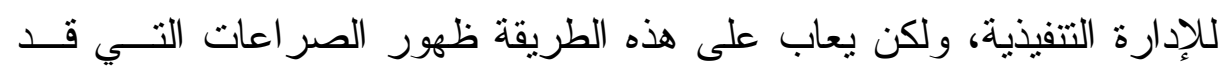
تعيق عملية الإصلاح الإداري. 


\section{المجلة |لعلمية لقطاع كليانه النجارة- جامعة الأزهر العدم |لعاشر - يناير سا.؟}

\section{المبحث الثالث}

\section{أبرز التجارب العربية في الإصلاح الإداري:}

اتضح من خلال العديد من الدراسات أن عملية الإصــلاح الإداري فـي

الدول العربية تعاني من اختلالات منباينة، أدت إلى عدم تكامل اســنز اتيجيات

الإصلاح، و عدم تحقيقها لأهدافها المرجوة، لعدة أسباب أهمها ما يلي ('):

1- تركيز جهود الإصلاح في الدول العربية على بنــاء الهياكــلـ والأنظمـــة

$$
\text { الرسمية. }
$$

Y- عدم اعتماد أسلوب المشاركة في عملية التطوير و التغيير الإداري. ب- الاهتمام بالجو انب الفنية و الإجر ائية، و إهمال الجو انب السلوكية و البيئيــة، وذلك من خلال التركيز على تطبيق الأساليب العلمية للإدارة.

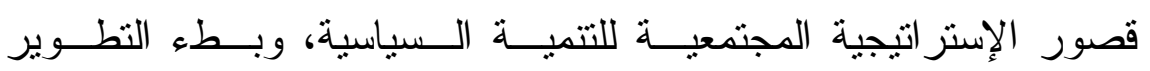
الايمقر اطي.

وهناك عدة تجارب للإصلاح الإداري في الوطن العربي، وقد اخترنا منها تجربتين هما: التجربة المصرية، و التجربة الكويتية، وسأقوم بعـرض لمحسـة موجزة من هاتين التجربنتي، بما يسمح به حجم هذا البحث.

\section{أولا: التنجربـة الكوبتنبة:}

بدأت محاو لات الإصلاح الإداري في دولة الكويت منذ تأسيسها، وتمثلـــت تلاك المحاو لات في مجموعة من الدر اسات التحليلية المتخصصة، وكذلك مـن خلال الاستعانة بخبر اء ومستشارين في مجال التتمية الإدارية، أو وضع خطط

(') سامي محمد أحمد البحيري(1) (1)، مداخـــل الإصلاح الإداري - التظوير التنظيــي

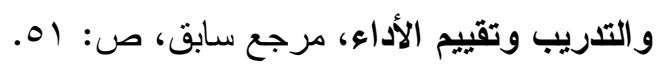




\section{المجلة|لعلمية لقطاع كليانه النجارة- جامعة الأزهر العدم |لعاشر - يناير سا.؟}

وبر امج لإصلاح أوضاع ومشكلات إدارية معينة، إلا أن خطة التتمية الخمية

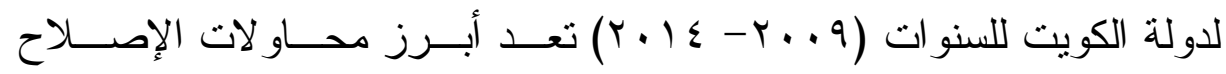
الإداري و التتموي الثـامل لدولة الكويت في العصر الحديث، حيــث اثـــتملت على جميع المجالات السياسية و الاجتماعية و الاقتصادية و الثقافيــة، وقــدمت

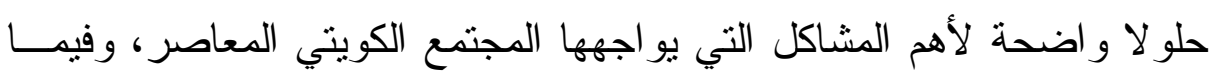
يلي عرض لأهم أهداف خطة التتمية الخمسية(') 1- استعادة الدور الريادي الإقليمي لدولة الكويت كمركز مالي وتجاري، سبق

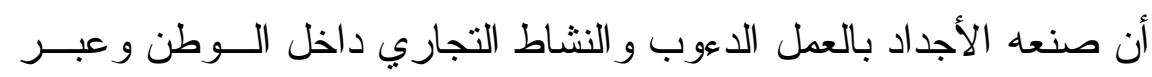
الحدود. وهي تتزجم رغبة أميرية سامية لصاحب السمو الأمير.

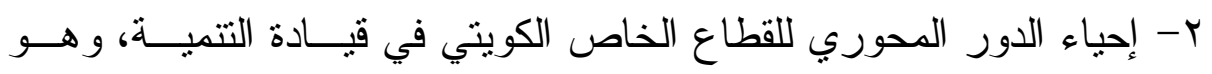
الدور الذي سبق أن حقق الريادة الكويتية التجارية في السابق ويؤمسـل أن

$$
\text { يعيد تحقيقها على أسس حديثة. }
$$

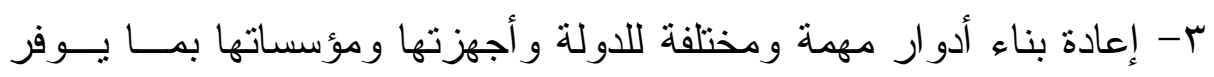
أسباب التمكين و الدعم للعمل و الإنتاج ويوفر البنية التحتيــة و التــشريعات المناسبة وبيئة الأعمال المواتية و المحفزة للتنمية. ع- توفير الضو ابط و المناخ لضمان التنمية البشرية الكلية و المتو ازنة و الهادفة

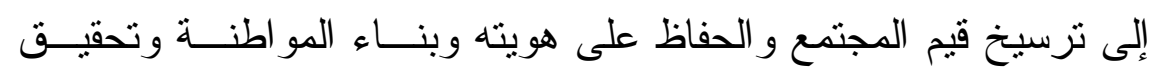
العدالة وسبل العيش الكريم.

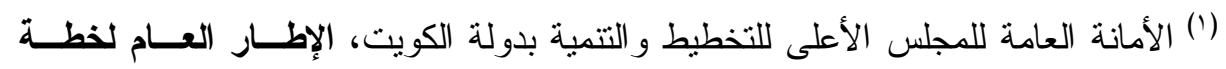

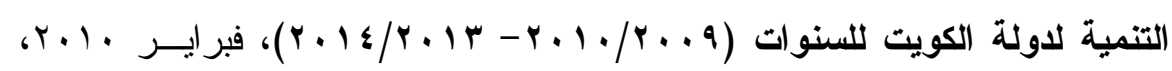

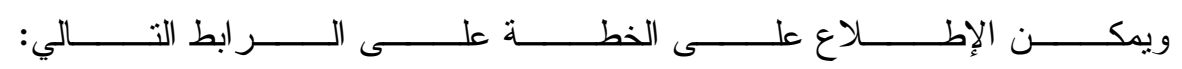
http://www.scpd.gov.kw/arabic/DocLib1/Final-Mid_range_plan.pdf 


\section{المجلة|لعلمية لقطاع كليانه النجارة- جامعة الأزهر العدم |لعاشر - يناير سا.؟}

ه- تدعيم وترسيخ النظام الديمقر اطي القائم على احتر ام الاستور و الالتز ام به ضمانا للعدالة و المشاركة السياسية و الحريات.

كما تضمنت الخطة أهدافا بعيدة المدى حتى عام هب • ب هي: 1- زيادة الناتج المحلي الإجمالي ورفع مستوى معيشة المواطن. r- القطاع الخاص يقود التتمية وفق آليات محفزة. r- دعم التتمية البشرية و المجتمعية. ع - تطوير السياسات السكانية لدعم التتمية. 0- - م- الإدارة الحكومية الفعالة.

كما اشتملت الخطة على مجموعة من السياسات الهادفــة إلــى إصــلاح الإدارة العامة و التخطيط و المعلومات، تتمتل فيما يلي:

\section{أولا: سباسات الإدارة الهكومية والشفافية والمساءلة، وتنشمل:}

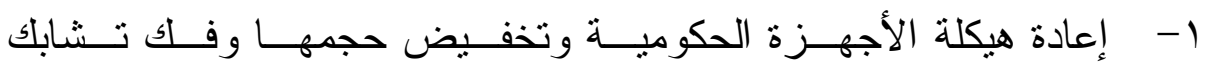
الاختصاصات فيما بينها من خلال تحديث الهياكل التتظيمية و إعداد أدلة

$$
\text { تتظيمية في الجهات الحكومية. }
$$

r- تطوير وضبط وتخفيض الهياكل الوظيفية في القطــــاع الحكـــومي مــن خلال الانتهاء من تطبيق جميع المجموعات الوظيفية للخدمــة المدنيــة خلال فترة الخطة. r- - الارتقاء بنوعية أداء وسبل تقديم الخــدمات العامـــة وخــدمات قطـــاع الأعمال من خلال تبسيط إجر اءات وتحديث دليل الخدمات العامة.

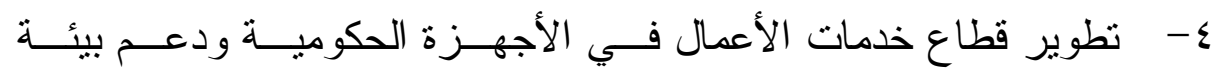
الاستثمار عبر الخدمات الالكترونية المناسبة، بما بـسهم فـي تحسـين وضع الكويت على مؤشر ممارسة الأعمال للبنك الدولي. 


\section{المجلة |لعلمية لقطاع كليانه النجارة- جامعة الأزهر العدم |لعاشر - يناير سا.؟}

0- در اسة تخصيص بعض الخدمات الحكومية أو تكليف القطـــاع الخــاص

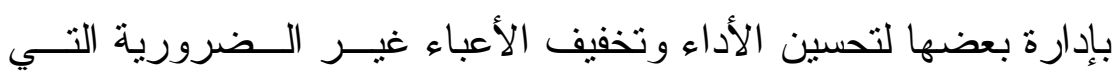
تتحملها الدولة.

7- استكمال مشروعات الحكومة الالكترونية وتطوير القــائم منهـــا عبــر تأسيس مر اكز الخدمات الالكترونية الثاملة، و المشروعات الداعمة لهــــا بما في ذلك مشروع البو ابة الرسمية الإكترونية للكويت.

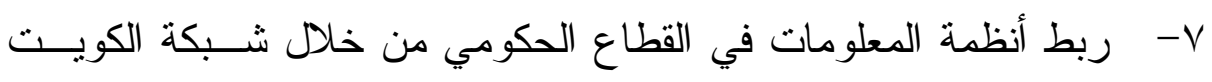

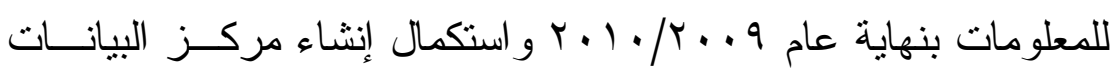

$$
\text { الوطني للقطاع الحكومي. }
$$

1- - تطوير القيادات في القطاع الحكومي لتحسـين كفـــاءة الأداء و التعامــلـ الإيجابي مع قطاعات الأعمال و إنشاء مركز متخصص لإعداد القيادات

$$
\text { الإدارية الحكومية. }
$$

9- ت تفعيل تطوير الأطر التشريعية والآليات المؤسـسية لمكافحــة الفـساد وتعزيز الثفافية في المجتمع و الاقتصاد، بما يدعم التتمية ويحسن نرنيب الكويت على مؤشر الثفافية العالمي، وبما يتو افق مع المتطلبات الدولية

$$
\text { في هذا الخصوص. }
$$

• - إصدار قانون مكافحة الفساد و إنشاء هيئة لمكافحة الفساد. 11 - تعزيز دور منظمات المجتمع المدني النوعية في مجال الثنفافية ومكافحة

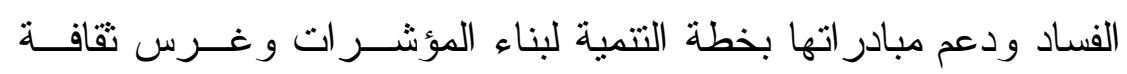
وممارسات الثفافية و المساءلة الإيجابية في المجتمع و الاقتصاد و الإدارة العامة بالتعاون مع الأجهزة المعنية. 


\section{المجلة|لعلمية لقطاع كليانه النجارة- جامعة الأزهر العدم |لعاشر - يناير سا.؟}

\section{ثانيا: سياسات التنطيط والإهصاءه وتتنمثل فيها بلي:}

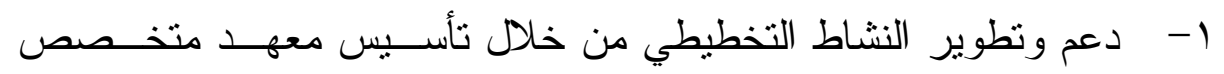
للتخطيط و الإحصاء و إعداد در اسات نوعية تغطـي قـــايا مـستقبلية

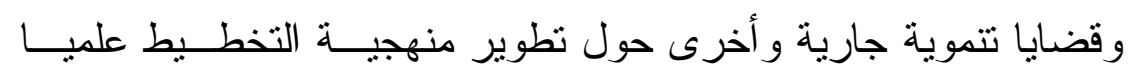
و عمليا بالتتسيق مع المجلس الأعلى للتخطيط و التتمية. r- تقعيل وظيفة التخطيط في المؤسسات الحكومية و إثناعة ثقافة التخطــــ من خلا إعداد دليل علمي للتخطيط على مستوى الدولة يبين المنهجيــة و الأدو ات بشكل مفصل، وتدريب القائمين على التخطيط بشكل منهجيـي

$$
\text { و عبر إطار موحد. }
$$

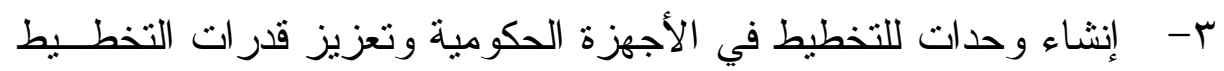
الاستز اتيجي فيها، وتدريب الكو ادر الفنية في الأجهزة الحكومية من قبل الأمانة العامة للمجلس الأعلى للتخطيط و التتمية. ع - الاهتمام بنشاط المتابعة للخطط و البر امج وتطـــويره وتفعيلـــه كنـششاط تتموي من خلال مفترح بخطة التنمية لإنثاء منظومة متكاملة لمتابعسة خطط التتمية وبر امج عمل الحكومة.

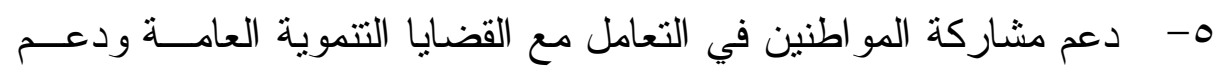
الإعلام التتموي و التسويق الاجتماعي لمشروعات التتمية مسن خــلد مشاريع متخصصة.

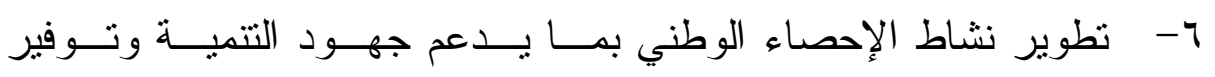
المعلومات الدقيقة لصناع السياسات العامة ومتخذي القــر ار وقطاعــات

$$
\text { الأعمال و الجهات الخارجية. }
$$




\section{المجلة|لعلمية لقطاع كليانه النجارة- جامعة الأزهر العدم |لعاشر - يناير سا.؟}

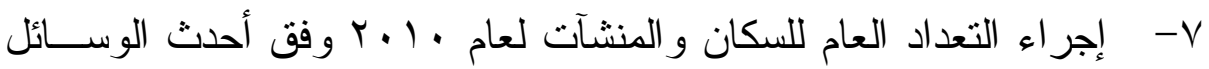

$$
\text { و الأدو ات. }
$$

1- - تطوير بنوك المعلومات و الخدمات الإحــصائية فــي الإدارة المركزيـــة للإحصاء و هيئة المعلومات المدنية.

9- تطوير المؤشرات الإحصائية في عدد من المجالات الهامة، مثل: تمكين المر أة و البطالة، ومسح القـوى العاملـــة، ومسـسـح العقــار ات الــسكنية و الاستثمارية، وقياس ثقة المستهلك.

• 1- بناء قو اعد المعلومات و المؤشر ات الاقتصادية المختلفة وتوفير ها بـشكل

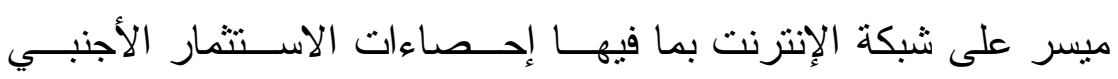

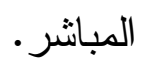

11 - تطوير الخدمات الإحصائية في نظام المعلومــات المدنيــة واســتكمال

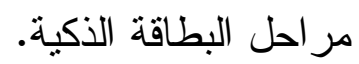

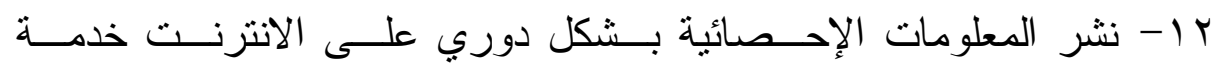
للمستقيدين، مع التركيز على توفير ها للقطاعات الاقتصادية المختلفة.

\section{ثالثا: سباسات مجتمعر المعلومات:}

1- إعادة هيكلة قطاع المعلومات و الاتصالات تشريعيا ومؤسسيا، من خــلد استكمال استحداث وتطوير التشريعات ذات العلاقة ومنها: إصدار قــانون جديد للاتصالات، وقانون التجارة و المعلومات الالكترونية، وقانون حماية الخصوصية والسرية، وقانون الكود الموحد، وتطوير قانون حماية الملكية

$$
\text { الفكرية. }
$$

r- استكمال التطوير المؤسسي لقطاع الاتصالات و المعلومات وذلك بإنـشاء هيئة تتظيم قطاع الاتصالات ومؤسسة البريد. 


\section{المجلة|لعلمية لقطاع كليانه النجارة- جامعة الأزهر العدم |لعاشر - يناير سا.؟}

ץ- تطوير وتحديث البنية التحتية للاتصالات و المعلومات من خلال اســتكمال تغطية كافة مناطق الدولة بالخدمة الهاتقية وشبكة الألياف الضوئية لتوفير خدمات الإنترنت بكافة المنــاطق، وضــبط وحمايــة البنيــة الأساســية لتكنولوجيا المعلومات و الاتصالات.

ع - استكمال تحرير قطاع الاتصالات وذلك بخصخصة بعض خدماتــهـ مثـلـ الهو اتف الثابتة في الدولة بعد الانتهاء من مشروعات إعادة تأهيل وتطوير شبكات الاتصالات الهاتفية في الكويت.

ه- توسيع الاهتمام بأمن المعلومات و إدارة الكوارث و الأزمات المعلوماتية من خلال مشروع متكامل للجهاز المركزي لتكنولوجيا المعلومات. 7- استكمال مقومات تطوير مجتمع المعلومات من خــلال إعــداد در اســات وتقارير سنوية ودورية حول مقومات ومتطلبات ومؤشرات تطور مجتمع المعلومات الكويتي من جانب الجهاز المركزي لتكنولوجيا المعلومات. V- الارتقاء بالعاملين في مجال المعلومات و الاتصالات مــن خــلال بــر امج مخططة للجهاز المركزي لتكنولوجيا المعلومات بالتعــاون مــع الجهـات الحكومية المعنية و القطاع الخاص ومنظمات المجتمع المدني المعنية. 1- نشر ثقافة المعلومات وتطبيقاتها في المجتمع من خلال بر امج مشتركة بين الجهاز المركزي لتكنولوجيــا المعلومــات ووزارات التزبيــة و الإعــلام ومنظمات المجتمع المدني المعنية. و على الرغم من شمولية خطة النطوير الإداري المشار إليها أعلاه كجزء

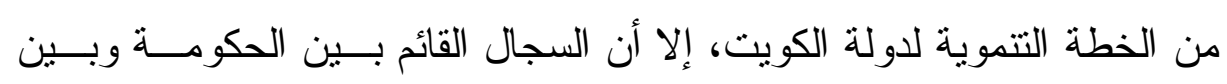

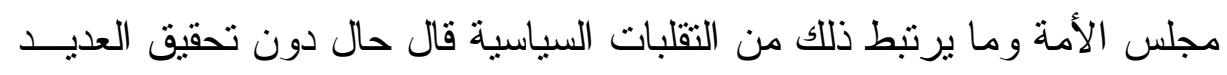




\section{المجلة|لعلمية لقطاع كليانه النجارة- جامعة الأزهر العدم |لعاشر - يناير سا.؟}

من الأهداف و البر امج المقررة وفق الخطة التتموية الثاملة، وهو ما يعنـي أن تجربة الإصلاح الإداري بدولة الكويت تحتاج إلى مزيد من التقويم.

\section{ثانبيا: التجربة المصرية:}

يرجع تاريخ التجربة المصرية للإصلاح الإداري إلى عام 1901 عنــدما

قامت الحكومة المصرية بدعوة السيد بول سينكر رئيس لجنة الخدمة المدنيــة البريطانية لدر اسة نظام الخدمة المدنية في مصر ، وقد أسفرت الدر اســـة عــن

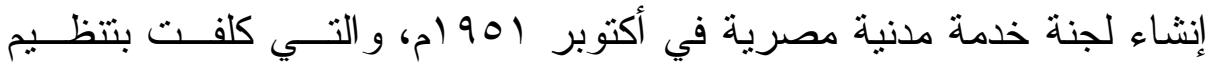
ومتابعة نظام إدارة العاملين بالدولة، وفي عام سجو ام تم عقد مؤتمر خــاص

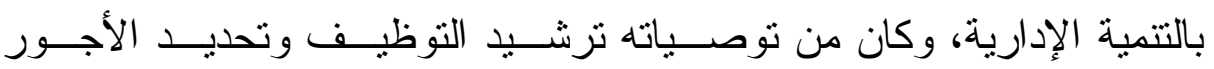
و السياسات التي تتعلق بشئون العاملين في الحكومة المــصرية، كمـــا أســفر المؤتمر عن إنشاء الجهاز المركزي للتنظيم و الإدارة بالقرار رقم (1 ( ) لسنة ع 9 (م، ليكون مسئو لا عن تتمية الإدارة و الخدمة المدنية في مصر ('). معالم برنامج الإصلاح الإداري في مصر: وضعت وزارة الدولة للتتمية الإدارية في مصر برنامجا و اضحا لتطــــير الجهاز الإداري في مصر ، وبدأت العمل به منذ عام ؟ . . بام، ويعتمد البرنامج

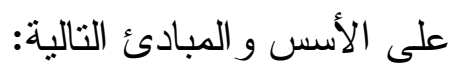
1- خلق المنافسة في نظام تقديم الخدمات الحكومية. r- (- بادة المشاركة المجتمعية.

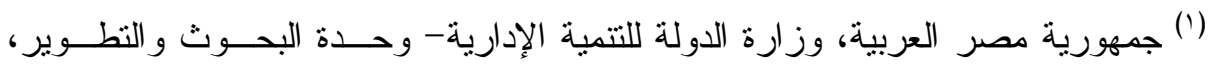

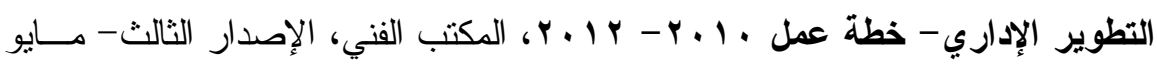

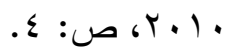




\section{المجلة|لعلمية لقطاع كليانه النجارة- جامعة الأزهر العدم |لعاشر - يناير سا.؟}

ب- تحسين مستوى الإنتاج و الدقة و الأداء داخـلـل منظومـــة العمـلـل الإداري بالدولة، مع التأكيد على وضع معايير و آليات لرصد ومكافحة الفساد به. ع- وضع آليات عدة للوصول إلى الثفافية و إتاحة المعلومات، ونظم مسساءلة للممارسات الإدارية في الحكومة على درجة عالية من الكفاءة. ه- التأكيد على ضرورة مشاركة المو اطنين فــي عمليــات بنــاء المـشـاركة التنموية.

7- تحليل ورسم السياسات المستقبلية داخل الجهاز الإداري للدولة، وذلك عن طريق استخدام نظم و أدوات أفضل للمساعدة في اتخاذ القرار. ولكن نظرا لعدة أسباب اجتماعية وسياسية واقتصادية فإن برنامج الإصــلاح الإداري لم يحقق النتائج المرجوة، وظل الجهاز الإداري في مصر يعاني مـن المظاهر السلبية التي تعوق عمليات الإصلاح الإداري أهمها ما يلي: 1- عدم ملاعمة حجم الجهاز الإداري مع المهام الموكلة إليه. r- التضارب في الوظائف و المسئوليات في الجهاز الإداري. r- الجمود البيروقر اطي و عدم النوازن في العمل داخله. ـ - ضعف أجور وحو افز العاملين.

ه- معظم محاو لات الإصـلاح الإداري التي نفذت علــى الوحــــات الإداريــة المحلية كانت غير منتظمة وغير مستمرة.

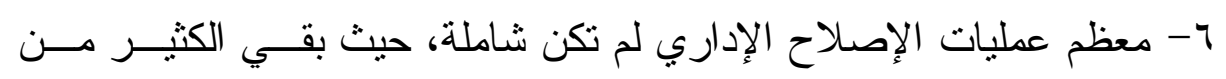
المحافظات المصرية تعاني من عدم الكفاءة الإدارية.

V- التحديات التي فرضتها العولمة و التكنولوجيا الحديثة و آمـــال المــو اطنين المتز ايدة أصبحت تشكل عبئا جديدا على كاهل الحكومة المصرية. 


\section{المجلة|لعلمية لقطاع كليانه النجارة- جامعة الأزهر العدم |لعاشر - يناير سا.؟}

\section{خلاصة البحث وأهم النتائج}

يمكن تلخيص أهم ما توصلت إليه هذه الار اسة من نتائج في النقاط التالية: 1- يهذف الإصلاح الإداري إلى تحقيق العديد من الأهداف أهمهــا: تحسسين

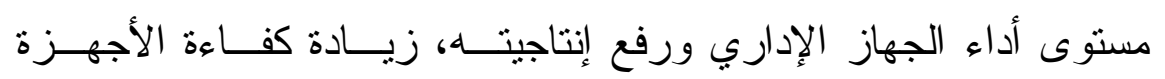
الحكومية، ترشيد الإنفاق الحكومي، التركيز على اقتــصاديات التـشغيل، تعزيز عملية التحول الديمقراطي، تبسيط الإجراءات الإداريــة، مو اكبـــة

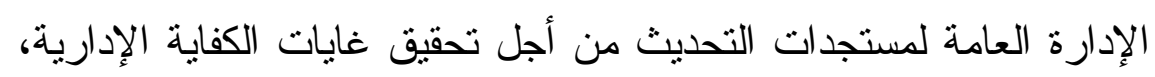
ومعالجة الانحر اف، ومحاربة الفساد، و القضاء على التعقيدات و العيــوب المرضية.

ץ- يتوقف نجاح الإصلاح الإداري على عدد من العوامل أهمها: بناء دولـــة القانون و المؤسسات، التي يسودها نطبيق القانون بمنأى عـن الاســنغلال و الرشوة و المظاهر الفاسدة، الاهتمام بالعنصر البشري، تكليف الأشخاص ذوي الكفاءة و النزاهة المطلوبة من الناحية العلمية و العملية، وضع بر امج تدرييية مدروسة لرفع كفاءة العاملين في الجهاز الحكومي مــن الناحيـة المهنية و السلوكية.

r- أهم معوقات الإصلاح الإداري: عدم استقر ار الوضع السياسي و الاجتماعي

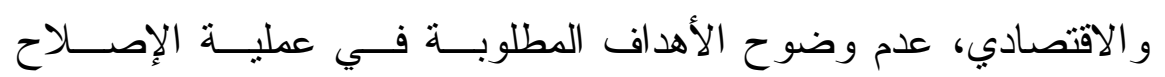
الإداري، وجود طبقة من الموظفين في مختلــف المسستويات الإداريـــة

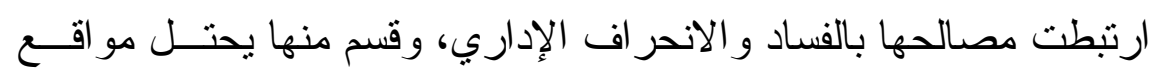

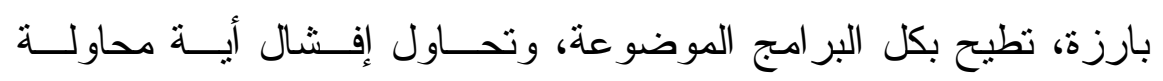

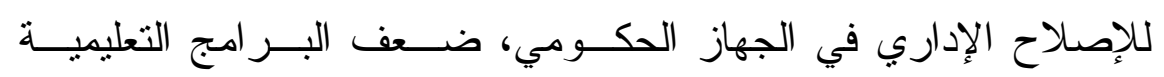
و التربوية. 


\section{المجلة|لعلمية لقطاع كليانه النجارة- جامعة الأزهر العدم |لعاشر - يناير سا.؟}

ع - نجت وزارة الدولة للتنمية الإدارية في مصر في وضع برنــامج واضــح

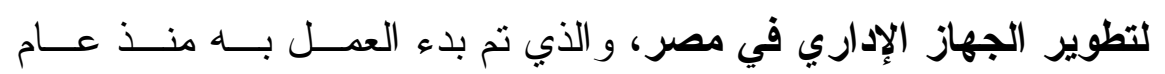

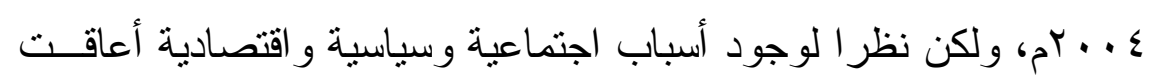

عملية الإصلاح الإداري، ظل الجهاز الإداري فـي مــصر يعساني مـنـ

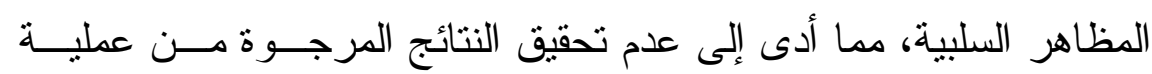

$$
\text { الإصصلاح الإداري. }
$$

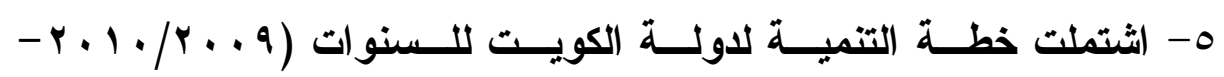

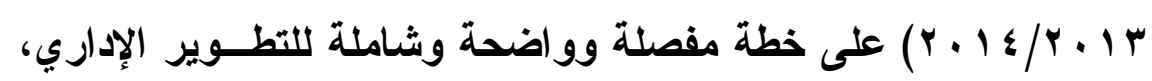

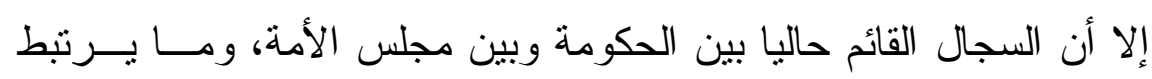
بذلك من التقلبات السياسية المستمرة في الكويت قد حال دون تحقيق العديد من الأهداف و البرامج المقررة وفق الخطة التتموية الثاملة، وهو ما يعني أن تجربة الإصلاح الإداري بدولة الكويت تحتاج إلى مزيد من التقويم.

\section{قائمة المراجع والمادر}

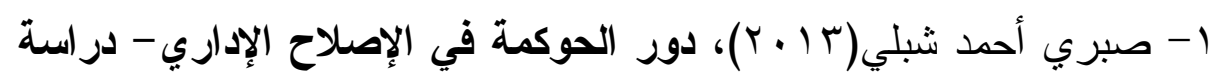
مقارنة بين الانمارك ولبنان، رسالة ماجستير مقدمــة إلــى الأكاديميـــة العربية في الدنمارك، كلية القانون و السياسة، قسم القانون. ץ- سامي محمد أحمد البحيري(1) (1)، مداخل الإصلاح الإداري - التطـــير التتظيمي والتدريب وتقيــيم الأداء، بحث مقدم للحصول على الماجـستير إلى الأكاديمية العربية البريطانية للتعليم العالي، لندن، المملكة المتحدة.

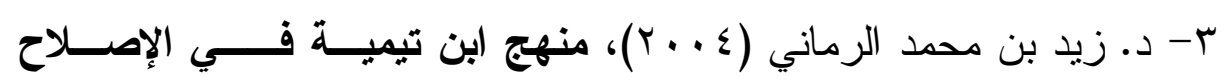
الإداري، دار الصميعي للنشر و التوزيع، الطبعة الأولى. 


\section{المجلة|لعلمية لقطاع كليانه النجارة- جامعة الأزهر العدم |لعاشر - يناير سا.؟}

ع- عبد الفتاح محمد علي الفرجاني (^ . . ب)، واقع اســتراتيجيات الإصــلاح والتطوير الإداري ودورها في تعزيز أمن المجتمع القلـسطيني"، رســالة ماجستير مقدمة إلى الجامعة الإسلامية بغزة، فلسطين.

ه- د. حاتم عثمان محمد خير، نحو أداء متميز للحكومات - تجربة جمهورية

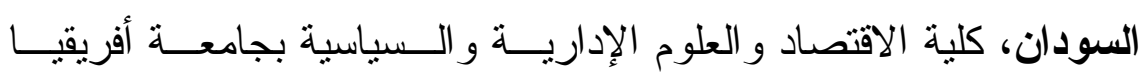

$$
\text { العالمية- الخرطوم، السودان. }
$$

7- أ.م.د. عادل طالب سالم، ومها فاروق عزت، أهمية العوامل المؤثرة فــي

الإصلاح الإداري لمواجهة الفساد، المعهد الطبي الثقني/المنصور.

V - سلمان سلامة، الإصلاح الإداري، أطروحة رسالة ماجستير مقدمسـة إلـى الـى

كلية الاقتصاد - جامعة دمشق، للحصول على درجة الماجستير فـي إدارة

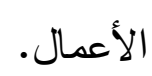

1- جمهورية مصر العربية، وزارة الدولة للتنمية الإدارية- وحــدة البحــوث

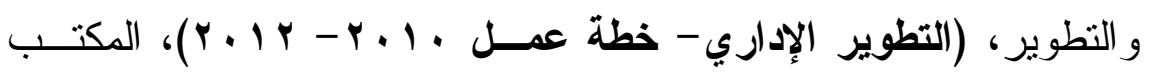

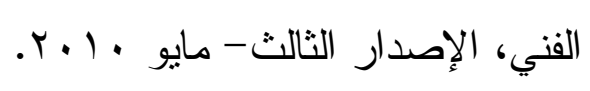

9- الأمانة العامة للمجلس الأعلى للتخطيط و التتمية بدولة الكويــــ" الإطـــار

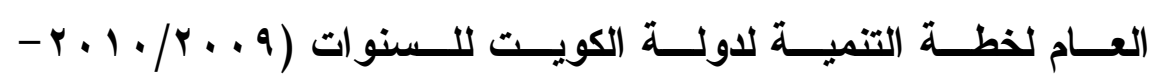

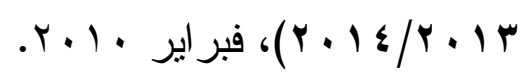

